\title{
Rootstock-scion interaction: 5. Effect on the evolution of Cabernet Sauvignon grape ripening
}

\author{
Alberto Miele ${ }^{1} \&$ Luiz Antenor Rizzon ${ }^{2}$ \\ Abstract - The rootstock effect on grapevine yield components, grape must and wine composition \\ and wine sensory characteristics were evaluated in previous studies. This experiment carried \\ out over five years had the objective to determine the effect of the rootstock on the evolution of \\ variables related to sugar and acidity contents of the juice during grape ripening. The treatments \\ consisted of Cabernet Sauvignon grapevine grafted on rootstocks such as Rupestris du Lot, 101- \\ 14 Mgt, 3309 C, 420A Mgt, 5BB K, 161-49 C, SO4, Solferino, 1103 P, 99 R, 110 R, Gravesac, \\ Fercal, Dogridge and Isabel. The berries were sampled during the grape ripening period, on nine \\ dates during the summer of each year. Taken to the laboratory, they were hand crushed and the \\ juice was centrifuged to separate the solid and liquid phase, where the supernatant was then used \\ for physicochemical analyses. The data were submitted to Principal Component Analysis (PCA) \\ and polynomial regression analysis. The main results show that, at grape maturity, the PCA \\ discriminated mainly the juices of CS/101-14 Mgt, CS/SO4 and CS/Gravesac, which had high \\ density, total soluble solids, total soluble solids/titratable acidity ratio and $\mathrm{pH}$, and $\mathrm{CS} /$ Dogridge \\ and CS/Fercal, which had high titratable acidity. The density, total soluble solids, titratable acidity, \\ total soluble solids/titratable acidity ratio increased as grape ripened, but the titratable acidity \\ decreased. However, the increase or decrease rates were lower at the end of the grape ripening \\ cycle according to the variable, and the total soluble solids having the highest increase $(116.3 \%)$ \\ and the titratable acidity the highest decrease (68.3\%). \\ Index terms: Vitis vinifera, viticulture, juice, maturation, composition. \section{Efeito na evolução da maturação da uva Cabernet Sauvignon} \\ Interação entre porta-enxerto e copa:
}

\section{Corresponding author: alberto.miele@embrapa.br \\ Received: September 26, 2017 Accepted: January 15, 2018}

Copyright: All the contents of this journal, except where otherwise noted, is licensed under a Creative Commons Attribution License.

\section{(cc) $\mathbf{E Y}$}

Resumo - Trabalhos anteriores avaliaram o efeito do porta-enxerto sobre os componentes de produção da videira, da composição do mosto e do vinho, e das características sensoriais do vinho. Neste experimento, conduzido durante cinco anos, o objetivo foi determinar o efeito do porta-enxerto na evolução de variáveis relacionadas a teores de açúcar e acidez do mosto da uva Cabernet Sauvignon enxertada sobre os porta-enxertos Rupestris du Lot, 101-14 Mgt, C 3309, 420A Mgt, K 5BB, C 161-49, SO4, Solferino, P 1103, R 99, R 110, Gravesac, Fercal, Dogridge e Isabel. As bagas foram amostradas na maturação da uva, em nove datas dos meses de verão de cada ano. No laboratório, elas foram esmagadas à mão, sendo o mosto centrifugado para separar a fase sólida da líquida, e o sobrenadante, utilizado para as análises físico-químicas. Os dados foram submetidos à Análise de Componentes Principais (ACP) e à análise de regressão polinomial. Os principais resultados mostram que, na maturidade, a ACP discriminou principalmente os mostos de CS/101-14 Mgt, CS/SO4 e CS/Gravesac - que tiveram elevada densidade, sólidos solúveis totais, relação sólidos solúveis totais/acidez titulável e pH - e CS/Dogridge e CS/Fercal, que tiveram elevada acidez titulável. A densidade, os sólidos solúveis totais, a acidez titulável e a relação sólidos solúveis totais/acidez titulável aumentaram à medida que a uva amadurecia, mas a acidez titulável diminuiu. No entanto, as taxas de crescimento ou de diminuição foram menores no final do ciclo de maturação da uva, de acordo com a variável, sendo que o maior aumento foi constatado nos sólidos solúveis totais (116,3\%) e a maior diminuição, na acidez titulável (68,3\%). Termos para indexação: Vitis vinifera, viticultura, mosto, maturação, composição. 


\section{Introduction}

The grapevines are grafted in almost all regions of the world due to the presence of phylloxera (Daktulosphaira vitifoliae Fitch, Homoptera: Phylloxeridae) which feeds on the sap of grapevine roots. To avoid this problem, grafting is beginning to be done as a precaution in regions where the presence of this insect has not yet been detected.

Initially, rootstocks were only of American species, especially Vitis riparia L., V. rupestris L. and $V$. berlandieri L., but currently there are also rootstocks of crosses between different species resistant to phylloxera. Each rootstock presents different adaptability to soil characteristics, resistance to fungi, insects - mainly phylloxera - and nematodes. They can also induce differences in the vigor of the rootstock (WINKLER et al., 1974), which influences the physiology of the vine, yield components, phenology, fruitfulness and berry size, color and composition. The rootstock effect on the vigor and yield components of the Cabernet Sauvignon grapevine cultivated in the Serra Gaúcha wine region has been studied (MIELE; RIZZON, 2017a). However, there are experiments conducted around the world showing different results (JONES et al., 2009; KELLER et al., 2012), which means each trial has results expressing the genetic material used and the climatic and soil characteristics of places where they were carried out.

The grape composition was also investigated, especially related to the effect on the total soluble solids, titratable acidity and pH (SATISHA et al., 2010; LEÃO et al., 2011; KAMILOGLU, 2012; KELLER et al., 2012; SOUZA et al., 2015; MIELE; RIZZON, 2017b). However, the effect of the rootstock on the variables related to sugar and the acidity of the juice during grape ripening was poorly evaluated (KASERER et al., 1996; CHOU; LI, 2014).

The effect of the rootstock on the evolution of these variables and the rate at which they evolved during the grape ripening period is a problem to be determined because it allows to know the composition of the juice at each date of the ripening period and to plan the grape harvest. In this sense, the purpose of this study was to determining the evolution of berry juice composition during the ripening period of Cabernet Sauvignon grapevine grafted onto different rootstocks.

\section{Material and Methods}

The experiment was carried out over five years from the 1999 to the 2003 vintages, in Serra Gaúcha, the most important Brazilian viticultural region. The coordinates were $29^{\circ} 09^{\prime} 44^{\prime \prime} \mathrm{S}$ and $51^{\circ} 31^{\prime} 50^{\prime}$ ' W, $640 \mathrm{~m}$ high and the annual climatological normal (1981-2010) for temperature is $17.4^{\circ} \mathrm{C}$ and for rain is $1,781 \mathrm{~mm}$.

The vineyard was established in a Cambissolo soil (FLORES et al., 2012), which is equivalent to an Inceptisol soil according to the Soil Taxonomy. Vineyard-related data such as soil characteristics, planting, trellising, vine spacing, pruning and training, canopy management and control of diseases, pests and weeds were described in previous study (MIELE; RIZZON, 2017a).

Cabernet Sauvignon grapevine ( $V$. vinifera L.) was grafted on fifteen rootstocks, namely Rupestris du Lot, 101-14 Millardet et de Grasset, 3309 Couderc, 420A Millardet et de Grasset, 5BB Kober, 161-49 Couderc, SO4, 1103 Paulsen, 99 Richter, 110 Richter, Gravesac, Fercal, Dogridge, Isabel and Solferino (local name of an unknown rootstock). The rootstocks species, including the crosses, were shown by Miele and Rizzon (2017a). Isabel (V. labrusca L.) is not a rootstock, but the most cultivated grapevine (mostly own rooted) in Serra Gaúcha, which production is primarily for wineries to make wine and grape juice.

The vineyard consisted of plots of 10 plants each, and the replicates were distributed in three blocks (150 plants per block and 450 plants in the experiment), which reduced the spatial variability of the soil. However, sampling did not consider replicates. Therefore, for each year, the evolution of grape ripening was evaluated at nine dates by harvesting berries from 30 plants per treatment $(4,050$ plants in total). The average dates of the five-year evaluation were January $13^{\text {th }}$ (day 1 ), $20^{\text {th }}$ (day 2 ), $26^{\text {th }}$ (day 3 ) and February $1^{\text {st }}$ (day 4), $7^{\text {th }}$ (day 5), $14^{\text {th }}$ (day 6), $18^{\text {th }}$ (day 7$), 24^{\text {th }}$ (day 8 ) and $28^{\text {th }}$ (day 9). Grape sampling began about one week after veraison, which consisted of the random withdrawal of 10 healthy berries per plant at each date. Daily determinations were made with a hand refractometer to determine the total soluble solids of the grape in the final ripening period. When the ${ }^{\circ}$ Brix has not changed, berries were then placed in plastic bags, taken to the laboratory as soon as the sampling was over, crushed with hands and juice centrifuged. The supernatant was then used for juice analysis.

Variables related to sugar and acidity were evaluated, such as total soluble solids ( ${ }^{\circ}$ Brix) determined by an Abbe refractometer (American Optical Corporation), with temperature correction; density $\left(\mathrm{g} \mathrm{mL}^{-1}\right)$, by a Paar densimeter, with temperature correction as well; titratable acidity $\left(\right.$ meq $\left.\mathrm{L}^{-1}\right)$, by titration; and $\mathrm{pH}$, by a Corning pHmeter (RIBÉREAU-GAYON et al., 1982). Total soluble solids / titratable acidity ratio was determined by the formula: total soluble solids / (titratable acidity $\mathrm{x}$ 0.0075).

The increase or decrease of the parameters of each variable between the data of the first and the last date (day 1 and day 9, respectively) of evaluation was recorded for each Cabernet Sauvignon/rootstock combination according to the formula: increase $(\%)=[($ data of day 9 data of day 1) x 100] - 100. The same was done for each day, according to the formula: increase per day $=($ data of day 9 - data of day 1) / 47, where 47 represents the 
number of days from the first to the last sampling of the Cabernet Sauvignon grape. The mean data of each variable evaluated for the set of the 15 treatments (CS/rootstock) were submitted to polynomial regression analysis. In addition, Principal Component Analysis (PCA) was used to discriminate them according to the composition of the juices.

\section{Results and Discussion}

The data related to the physicochemical analyses of the ripening evolution of Cabernet Sauvignon grapes are shown for total soluble solids (Table 1), titratable acidity (Table 2), pH (Table 3), density (Table 4) and total soluble solids/titratable acidity ratio (Table 5). Total soluble solids, $\mathrm{pH}$, density and total soluble solids/titratable acidity ratio increased over this period and the titratable acidity decreased.

In the veraison, $\mathrm{PC} 1$ and $\mathrm{PC} 2$ were responsible for $97.09 \%$ of the total variation (Figure 1). PC1 discriminated mainly CS/101-14 Mgt and CS/161-49 C - which had high density, total soluble solids, total soluble solids/ titratable acidity ratio and $\mathrm{pH}$ - and CS/Isabel, CS/99 R, CS/Fercal and CS/Dogridge, which had high titratable acidity. PC2 showed CS/Rupestris du Lot with high $\mathrm{pH}$.

At maturity, PC1 and PC2 were responsible for $90.99 \%$ (Figure 2) of the total variation, where $\mathrm{PC} 1$ discriminated mainly CS/101-14 Mgt, CS/SO4 and CS/ Gravesac - which had high density, total soluble solids, total soluble solids/titratable acidity ratio and $\mathrm{pH}-$, and CS/Dogridge and CS/Fercal- which had high titratable acidity.
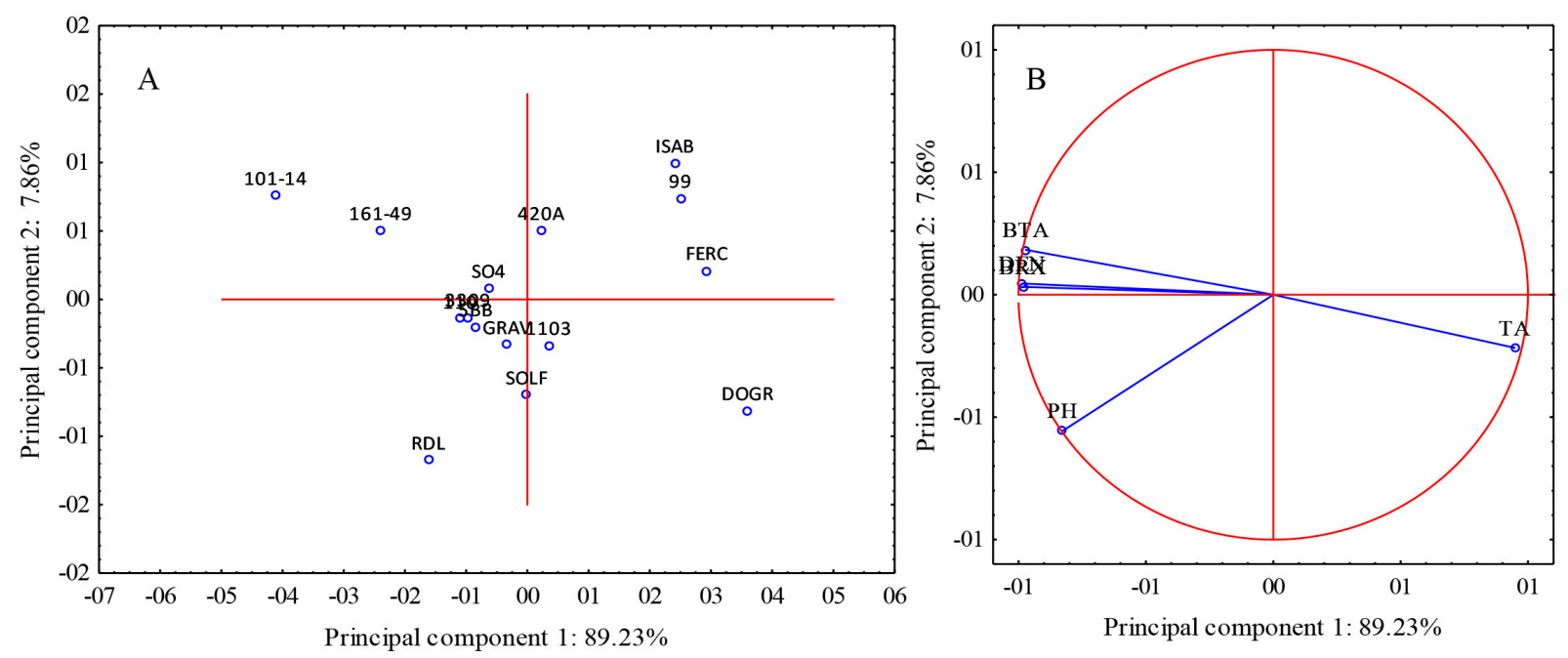

Figure 1 - Projection of Cabernet Sauvignon/rootstock combinations (A) and juice variables (B) in the veraison on the planes formed by the principal components 1 and 2. Legend $A$ : RDL=CS/Rupestris du Lot, 101-14=CS/101-14 Mgt, 3309=CS/3309 $\mathrm{C}, 420 \mathrm{~A}=\mathrm{CS} / 420 \mathrm{~A}$ Mgt, 5BB $=\mathrm{CS} / 5 \mathrm{BB} \mathrm{K}, 161-49=\mathrm{CS} / 161-49 \mathrm{C}, \mathrm{SO} 4=\mathrm{CS} / \mathrm{SO} 4, \mathrm{SOLF}=\mathrm{CS} /$ Solferino, $1103=\mathrm{CS} / 1103 \mathrm{P}, 99=$ $\mathrm{CS} / 99 \mathrm{R}, 110=\mathrm{CS} / 110 \mathrm{R}, \mathrm{GRAV}=\mathrm{CS} /$ Gravesac, $\mathrm{FERC}=\mathrm{CS} /$ Fercal, DOGR=CS/Dogridge, ISAB= CS/Isabel. Legend $B: \mathrm{BRX}=$ total soluble solids, $\mathrm{TA}=$ titratable acidity, $\mathrm{PH}=\mathrm{pH}, \mathrm{DEN}=$ density, $\mathrm{BTA}=$ total soluble solids/titratable acidity ratio.
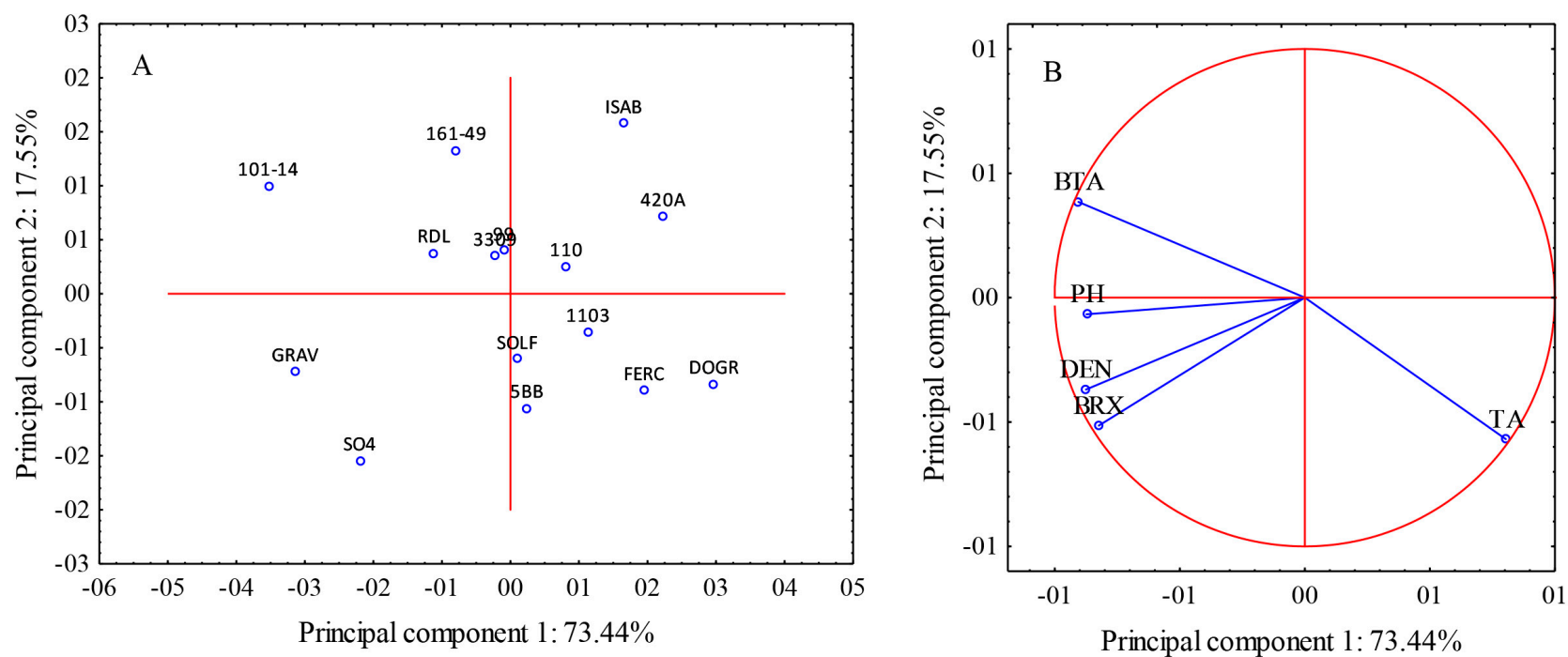

Figure 2 - Projection of Cabernet Sauvignon/rootstock combinations (A) and juice variables (B) at maturity on the planes formed by the principal components 1 and 2. Legend $A$ : $\mathrm{RDL}=\mathrm{CS} /$ Rupestris du Lot, 101-14=CS/101-14 Mgt, 3309=CS/3309 C, 420A= $\mathrm{CS} / 420$ A Mgt, 5BB= CS/5BB K, 161-49= CS/161-49 C, SO4= CS/SO4, SOLF= CS/Solferino, $1103=\mathrm{CS} / 1103$ P, $99=\mathrm{CS} / 99$ $\mathrm{R}, 110=\mathrm{CS} / 110 \mathrm{R}, \mathrm{GRAV}=\mathrm{CS} /$ Gravesac, FERC $=\mathrm{CS} /$ Fercal, DOGR= CS/Dogridge, ISAB= CS/Isabel. Legend $B: \mathrm{BRX}=$ total soluble solids, $\mathrm{TA}=$ titratable acidity, $\mathrm{PH}=\mathrm{pH}, \mathrm{DEN}=$ density, $\mathrm{BTA}=$ total soluble solids/titratable acidity ratio. 
The total soluble solids mean of all treatments increased $116.3 \%$ from veraison to maturity (Table 1 ), which evolution $(p<0.001)$ is shown in Figure 3 . The minimum value was $92.4 \%$ in CS/101-14 Mgt and the maximum $146.9 \%$ in $\mathrm{CS} / 99 \mathrm{R}$. The total soluble solids increase per day was $0.228 \pm 0.015{ }^{\circ} \mathrm{Brix}$, ranging from 0.206 in CS/101-14 Mgt to 0.253 in CS/99 R. However, the titratable acidity mean of all treatments decreased $68.3 \%$ (Table 2 ), which evolution ( $p<0.001$ ) is also shown in Figure 3. The minimum value was $65.7 \%$ in $\mathrm{CS} / 5 \mathrm{BB}$ $\mathrm{K}$ and the maximum $70.0 \%$ in $\mathrm{CS} / \mathrm{Isabel}$. The titratable acidity decrease per day was $6.40 \pm 0.36 \mathrm{meq} \mathrm{L}^{-1}$, ranging from $5.87 \mathrm{meq} \mathrm{L}^{-1}$ in CS/161-49 $\mathrm{C}$ to $7.02 \mathrm{meq} \mathrm{L}^{-1}$ in CS/ Dogridge.

Table 1 - Evolution of total soluble solids ( ${ }^{\circ}$ Brix) during ripening of Cabernet Sauvignon grape grafted on different rootstocks. Means from 1999 to 2003.

\begin{tabular}{lccccccccc}
\hline Rootstock & ${\text { Jan } 13^{\text {th }}}^{\text {th }}$ & Jan 20 & Jan 26 & Feb $1^{\text {th }}$ & ${\text { Feb } 7^{\text {th }}}^{\text {th }}$ & Feb 14 $^{\text {th }}$ & Feb 18 $^{\text {th }}$ & Feb 24 $^{\text {th }}$ & Feb 28 $^{\text {th }}$ \\
\hline Rup. du Lot & 9.6 & 12.4 & 14.1 & 15.2 & 16.4 & 17.0 & 17.9 & 19.2 & 19.9 \\
101-14 Mgt & 10.5 & 13.2 & 14.7 & 15.6 & 17.0 & 17.8 & 18.5 & 19.4 & 20.2 \\
3309 C & 9.4 & 12.5 & 13.9 & 15.2 & 16.4 & 17.3 & 17.8 & 18.8 & 20.0 \\
420 A Mgt & 9.3 & 12.4 & 13.5 & 15.3 & 16.1 & 16.9 & 17.5 & 18.7 & 19.3 \\
5 BB K & 9.4 & 12.4 & 13.6 & 15.1 & 16.0 & 17.0 & 17.2 & 18.7 & 20.0 \\
161-49 C & 9.9 & 12.5 & 14.0 & 15.2 & 16.4 & 17.1 & 17.6 & 18.7 & 19.7 \\
SO4 & 9.4 & 12.4 & 14.0 & 15.2 & 16.0 & 17.2 & 18.0 & 18.8 & 20.8 \\
Solferino & 9.3 & 12.3 & 14.0 & 14.8 & 16.3 & 17.1 & 17.5 & 18.8 & 20.0 \\
1103 P & 9.1 & 12.2 & 13.4 & 14.8 & 15.9 & 16.7 & 17.4 & 18.5 & 19.7 \\
99 R & 8.1 & 11.3 & 13.3 & 14.5 & 15.7 & 16.7 & 17.2 & 18.6 & 20.0 \\
110 R & 9.6 & 12.4 & 13.7 & 14.9 & 16.0 & 16.7 & 17.6 & 18.8 & 19.5 \\
Gravesac & 9.1 & 12.7 & 14.3 & 15.4 & 16.6 & 17.6 & 18.2 & 19.4 & 20.7 \\
Fercal & 8.4 & 11.8 & 13.5 & 15.0 & 16.0 & 16.8 & 17.7 & 18.8 & 19.8 \\
Dogridge & 7.9 & 11.6 & 13.5 & 14.8 & 16.0 & 16.7 & 17.4 & 18.6 & 19.4 \\
Isabel & 8.5 & 11.9 & 13.4 & 15.1 & 15.9 & 16.8 & 17.4 & 18.8 & 19.3 \\
\hline Mean & 9.2 & 12.3 & 13.8 & 15.1 & 16.2 & 17.0 & 17.7 & 18.8 & 19.9 \\
\hline
\end{tabular}

Table 2 - Evolution of titratable acidity $\left(\mathrm{meq} \mathrm{L}^{-1}\right)$ during ripening of Cabernet Sauvignon grape grafted on different rootstocks. Means from 1999 to 2003.

\begin{tabular}{|c|c|c|c|c|c|c|c|c|c|}
\hline Rootstock & Jan $13^{\text {th }}$ & Jan $20^{\text {th }}$ & $\operatorname{Jan} 26^{\text {th }}$ & Feb $1^{\text {st }}$ & Feb $7^{\text {th }}$ & Feb $14^{\text {th }}$ & Feb $18^{\text {th }}$ & Feb $24^{\text {th }}$ & Feb $28^{\text {th }}$ \\
\hline Rup. du Lot & 430 & 312 & 263 & 218 & 191 & 179 & 164 & 144 & 133 \\
\hline 101-14 Mgt & 399 & 281 & 233 & 193 & 170 & 158 & 151 & 130 & 122 \\
\hline $3309 \mathrm{C}$ & 429 & 308 & 259 & 202 & 180 & 173 & 159 & 145 & 137 \\
\hline $420 \mathrm{~A} \mathrm{Mgt}$ & 446 & 330 & 274 & 214 & 192 & 184 & 169 & 154 & 145 \\
\hline 5 BB K & 437 & 334 & 279 & 221 & 196 & 180 & 176 & 149 & 150 \\
\hline $161-49 \mathrm{C}$ & 410 & 302 & 236 & 199 & 175 & 164 & 153 & 138 & 134 \\
\hline $\mathrm{SO} 4$ & 434 & 330 & 262 & 217 & 197 & 184 & 170 & 156 & 139 \\
\hline Solferino & 451 & 336 & 265 & 234 & 196 & 183 & 176 & 156 & 144 \\
\hline 1103 P & 448 & 346 & 272 & 218 & 198 & 184 & 172 & 153 & 146 \\
\hline $99 \mathrm{R}$ & 450 & 386 & 288 & 226 & 196 & 185 & 178 & 150 & 136 \\
\hline $110 \mathrm{R}$ & 431 & 312 & 252 & 187 & 187 & 186 & 167 & 145 & 141 \\
\hline Gravesac & 434 & 316 & 254 & 215 & 186 & 172 & 156 & 139 & 133 \\
\hline Fercal & 479 & 366 & 292 & 237 & 216 & 201 & 177 & 161 & 151 \\
\hline Dogridge & 486 & 369 & 299 & 243 & 214 & 200 & 188 & 172 & 156 \\
\hline Isabel & 456 & 337 & 266 & 204 & 188 & 175 & 166 & 146 & 137 \\
\hline Mean & 441 & 331 & 266 & 215 & 192 & 181 & 168 & 149 & 140 \\
\hline
\end{tabular}


The $\mathrm{pH}$ mean of all treatments increased $16.3 \%$ (Table 3), which evolution $(\mathrm{p}<0.001)$ is shown in Figure 4. The minimum value was $14.8 \%$ in $\mathrm{CS} / 110 \mathrm{R}$ and the maximum $17.3 \%$ in $\mathrm{CS} /$ Gravesac. The $\mathrm{pH}$ increase per day was $0.0010 \pm 0.0005$, ranging from $0.0087 \mathrm{in} \mathrm{CS} / 110 \mathrm{R}$ to 0.0102 in CS/Gravesac. The density mean of all treatments increased $4.44 \%$ (Table 4$)$, which evolution $(\mathrm{p}<0.001)$ is also shown in Figure 4. The minimum value was 3.99\% in $\mathrm{CS} / 161.49 \mathrm{C}$ and the maximum $4.85 \%$ in $\mathrm{CS} / 99 \mathrm{R}$. The density increase per day was $0.00098 \pm 0.00006 \mathrm{~g} \mathrm{~mL}^{-1}$, ranging from $0.00089 \mathrm{~g} \mathrm{~mL}^{-1}$ in $\mathrm{CS} / 161-49 \mathrm{C}$ to 0.00107 $\mathrm{g} \mathrm{mL}^{-1}$ in CS/99 R.

Table 3 - Evolution of pH during ripening of Cabernet Sauvignon grape grafted on different rootstocks. Means from 1999 to 2003.

\begin{tabular}{lccccccccc}
\hline Rootstock & ${\text { Jan } 13^{\text {th }}}$ Jan 20 $^{\text {th }}$ & Jan 26 $^{\text {th }}$ & Feb 1 $^{\text {st }}$ & ${\text { Feb } 7^{\text {th }}}$ & Feb 14 $^{\text {th }}$ & Feb 18 $^{\text {th }}$ & Feb 24 $^{\text {th }}$ & Feb 28 $^{\text {th }}$ \\
\hline Rup. du Lot & 2.80 & 2.86 & 2.94 & 3.04 & 3.08 & 3.11 & 3.12 & 3.17 & 3.23 \\
101-14 Mgt & 2.78 & 2.83 & 2.93 & 3.01 & 3.08 & 3.12 & 3.10 & 3.18 & 3.25 \\
3309 C & 2.77 & 2.83 & 2.90 & 3.04 & 3.07 & 3.11 & 3.09 & 3.14 & 3.20 \\
420 A Mgt & 2.74 & 2.81 & 2.86 & 2.98 & 3.02 & 3.05 & 3.04 & 3.11 & 3.16 \\
5 BB K & 2.77 & 2.80 & 2.90 & 3.01 & 3.06 & 3.10 & 3.07 & 3.15 & 3.22 \\
161-49 C & 2.77 & 2.83 & 2.92 & 3.00 & 3.06 & 3.09 & 3.09 & 3.15 & 3.24 \\
SO4 & 2.76 & 2.80 & 2.93 & 3.01 & 3.05 & 3.11 & 3.09 & 3.16 & 3.23 \\
Solferino & 2.77 & 2.81 & 2.91 & 2.96 & 3.03 & 3.09 & 3.08 & 3.13 & 3.21 \\
1103 P & 2.76 & 2.81 & 2.92 & 2.99 & 3.03 & 3.08 & 3.08 & 3.15 & 3.21 \\
99 R & 2.72 & 2.76 & 2.87 & 2.97 & 3.01 & 3.07 & 3.03 & 3.11 & 3.19 \\
110 R & 2.77 & 2.83 & 2.91 & 2.97 & 3.04 & 3.05 & 3.08 & 3.14 & 3.18 \\
Gravesac & 2.77 & 2.82 & 2.95 & 3.00 & 3.07 & 3.10 & 3.13 & 3.17 & 3.25 \\
Fercal & 2.72 & 2.77 & 2.88 & 2.97 & 3.00 & 3.05 & 3.07 & 3.11 & 3.17 \\
Dogridge & 2.74 & 2.80 & 2.91 & 3.01 & 3.04 & 3.11 & 3.08 & 3.11 & 3.19 \\
Isabel & 2.71 & 2.79 & 2.90 & 3.00 & 3.05 & 3.09 & 3.08 & 3.15 & 3.18 \\
\hline Mean & 2.76 & 2.81 & 2.91 & 3.00 & 3.05 & 3.09 & 3.08 & 3.14 & 3.21 \\
\hline
\end{tabular}

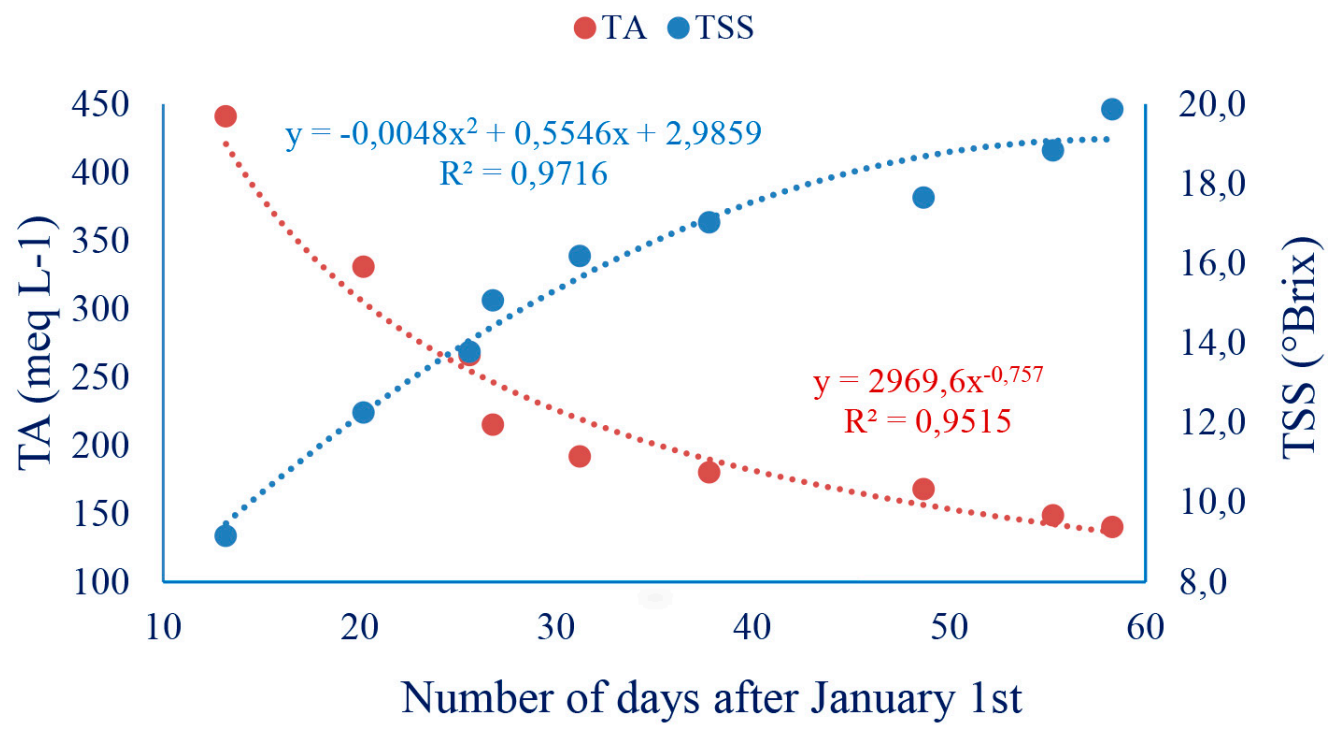

Figure 3 - Evolution of titratable acidity and total soluble solids during Cabernet Sauvignon grape ripening. Each point represents the five-year mean of the $15 \mathrm{CS} /$ rootstock combinations. 
Table 4 - Evolution of density $\left(\mathrm{g} \mathrm{mL}^{-1}\right)$ during ripening of Cabernet Sauvignon grape grafted on different rootstocks. Means from 1999 to 2003.

\begin{tabular}{lccccccccc}
\hline Rootstock & ${\text { Jan } 13^{\text {th }}}{\text { Jan } 20^{\text {th }}}^{\text {Jan 26 }}$ th $^{\text {th }}$ & Feb $1^{\text {st }}$ & Feb $7^{\text {th }}$ & Feb 14 & Feb 18 & Feb 24 & Feb 28 \\
\hline Rup. du Lot & 1.0421 & 1.0535 & 1.0605 & 1.0652 & 1.0705 & 1.0733 & 1.0772 & 1.0824 & 1.0876 \\
101-14 Mgt & 1.0461 & 1.0566 & 1.0631 & 1.0668 & 1.0725 & 1.0762 & 1.0800 & 1.0839 & 1.0901 \\
3309 C & 1.0417 & 1.0537 & 1.0598 & 1.0652 & 1.0700 & 1.0742 & 1.0761 & 1.0805 & 1.0863 \\
420 A Mgt & 1.0410 & 1.0531 & 1.0580 & 1.0653 & 1.0691 & 1.0722 & 1.0755 & 1.0806 & 1.0844 \\
5 BB K & 1.0413 & 1.0532 & 1.0591 & 1.0649 & 1.0692 & 1.0730 & 1.0749 & 1.0805 & 1.0871 \\
161-49 C & 1.0435 & 1.0542 & 1.0602 & 1.0649 & 1.0701 & 1.0741 & 1.0761 & 1.0809 & 1.0851 \\
SO4 & 1.0418 & 1.0533 & 1.0606 & 1.0650 & 1.0693 & 1.0738 & 1.0774 & 1.0813 & 1.0901 \\
Solferino & 1.0408 & 1.0530 & 1.0600 & 1.0636 & 1.0693 & 1.0727 & 1.0757 & 1.0810 & 1.0869 \\
1103 P & 1.0400 & 1.0523 & 1.0572 & 1.0636 & 1.0679 & 1.0712 & 1.0753 & 1.0793 & 1.0853 \\
99 R & 1.0363 & 1.0490 & 1.0570 & 1.0623 & 1.0673 & 1.0710 & 1.0741 & 1.0798 & 1.0866 \\
110 R & 1.0419 & 1.0533 & 1.0592 & 1.0640 & 1.0686 & 1.0712 & 1.0726 & 1.0811 & 1.0874 \\
Gravesac & 1.0403 & 1.0546 & 1.0614 & 1.0659 & 1.0707 & 1.0750 & 1.0789 & 1.0833 & 1.0900 \\
Fercal & 1.0372 & 1.0507 & 1.0584 & 1.0641 & 1.0685 & 1.0716 & 1.0759 & 1.0815 & 1.0857 \\
Dogridge & 1.0354 & 1.0503 & 1.0584 & 1.0632 & 1.0684 & 1.0715 & 1.0754 & 1.0798 & 1.0846 \\
Isabel & 1.0375 & 1.0512 & 1.0576 & 1.0647 & 1.0683 & 1.0720 & 1.0750 & 1.0800 & 1.0834 \\
\hline Mean & 1.0405 & 1.0528 & 1.0594 & 1.0646 & 1.0693 & 1.0729 & 1.0760 & 1.0811 & 1.0867 \\
\hline
\end{tabular}

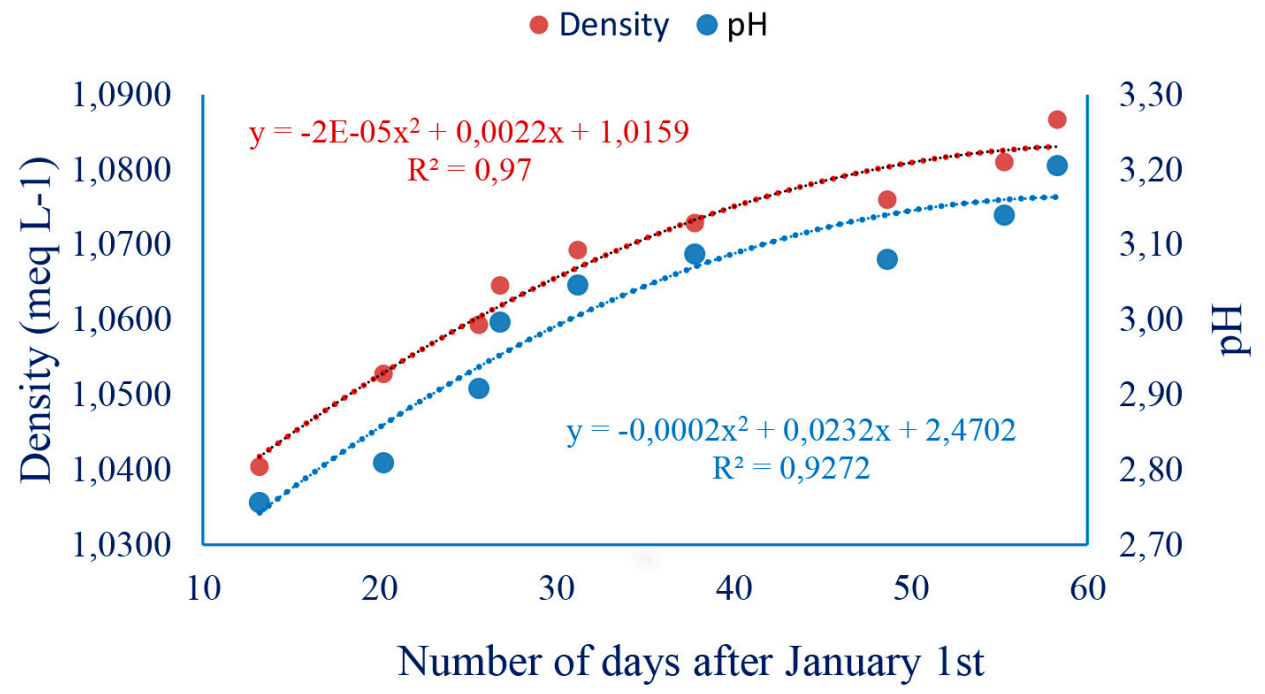

Figure 4 - Evolution of density and pH during Cabernet Sauvignon grape ripening. Each point represents the five-year mean of the $15 \mathrm{CS} /$ rootstock combinations. 
Table 5 - Evolution of total soluble solids/titratable acidity ratio during ripening of Cabernet Sauvignon grape grafted on different rootstocks. Means from 1999 to 2003.

\begin{tabular}{lccccccccc}
\hline Rootstock & ${\text { Jan } 13^{\text {th }}}^{\text {Jan 20 th }}$ & ${\text { Jan } 26^{\text {th }}}^{\text {th }}$ & Feb $1^{\text {st }}$ & Feb $7^{\text {th }}$ & Feb 14 & Feb 18 & Feb 24 $^{\text {th }}$ & Feb 28 $^{\text {th }}$ \\
\hline Rup. du Lot & 3.2 & 5.7 & 7.7 & 9.8 & 11.9 & 13.4 & 15.1 & 18.2 & 21.2 \\
101-14 Mgt & 4.1 & 6.7 & 8.9 & 11.4 & 13.9 & 15.6 & 17.0 & 20.9 & 23.2 \\
3309 C & 3.2 & 5.7 & 7.7 & 10.8 & 12.8 & 14.4 & 15.7 & 18.0 & 21.1 \\
420 A Mgt & 3.0 & 5.4 & 7.2 & 10.0 & 11.9 & 13.4 & 14.5 & 17.1 & 20.0 \\
5 BB K & 3.3 & 5.3 & 7.4 & 9.9 & 11.6 & 13.5 & 13.6 & 17.5 & 20.4 \\
161-49 C & 3.6 & 5.8 & 8.3 & 10.8 & 12.9 & 14.7 & 16.1 & 19.0 & 22.1 \\
SO4 & 3.1 & 5.4 & 7.8 & 10.0 & 11.4 & 13.2 & 14.6 & 16.9 & 21.3 \\
Solferino & 2.9 & 5.2 & 7.5 & 9.2 & 11.8 & 14.2 & 13.9 & 16.9 & 20.3 \\
1103 P & 2.9 & 5.1 & 7.0 & 9.7 & 11.2 & 12.8 & 14.0 & 17.0 & 19.4 \\
99 R & 2.7 & 4.2 & 6.5 & 9.1 & 11.1 & 12.7 & 13.5 & 17.1 & 21.1 \\
110 R & 3.2 & 5.8 & 7.7 & 12.1 & 12.0 & 13.1 & 14.8 & 18.3 & 20.5 \\
Gravesac & 3.1 & 5.8 & 7.9 & 10.2 & 12.4 & 14.2 & 16.0 & 19.3 & 22.3 \\
Fercal & 2.5 & 4.5 & 6.7 & 9.2 & 10.5 & 12.1 & 13.8 & 16.3 & 19.1 \\
Dogridge & 2.3 & 4.6 & 6.5 & 8.9 & 10.6 & 12.1 & 12.9 & 15.0 & 18.2 \\
Isabel & 2.6 & 5.1 & 7.1 & 10.4 & 11.9 & 13.7 & 14.7 & 18.2 & 20.5 \\
\hline Mean & 3.1 & 5.4 & 7.4 & 10.1 & 11.9 & 13.5 & 14.7 & 17.7 & 20.7 \\
\hline
\end{tabular}

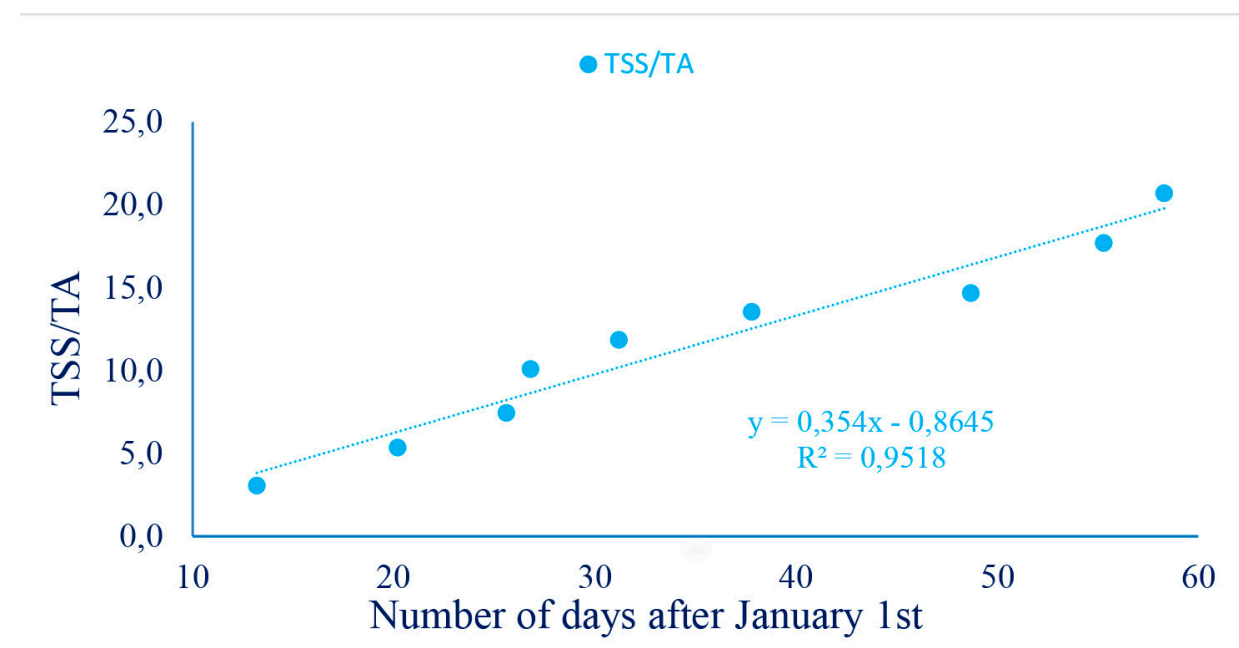

Figure 5 - Evolution of total soluble solids/titratable acidity ratio during Cabernet Sauvignon grape ripening. Each point represents the five-year mean of the $15 \mathrm{CS} /$ rootstock combinations. 
The total soluble solids/titratable acidity ratio mean of all treatments increased 6.68 fold (Table 5), which evolution $(p<0.001)$ is shown in Figure 5. The minimum value was 5.66 in CS/101-14 Mgt and the maximum 7.81 in CS/99 R. The total soluble solids/titratable acidity ratio increase per day was $0.36 \pm 0.02$, ranging from 0.34 in CS/ Dogridge to 0.41 in CS/101-14 Mgt and CS/Gravesac.

The increase rates in density and total soluble solids, which mainly represent the accumulation of glucose and fructose in fruits tended to decrease, and varied according to the $\mathrm{CS} /$ rootstock combination and from year to year. This behavior, indeed, was observed for all variables studied. In the same period, titratable acidity decreased as a function of the metabolism of organic acids, mainly tartaric and malic acids (KLIEWER, 1971), and its decrease rate was slower as the grape ripened. $\mathrm{pH}$ also increased, but its increase rate was similar to those of density and total soluble solids. Consequently, the total soluble solids/titratable acidity ratio showed behavior similar to the density, total soluble solids and $\mathrm{pH}$.

A more regular decrease in the rate of sugar accumulation in Cabernet Sauvignon grape was found by Nuzzo and Matthews (2006), suggesting that it was due to the grafting of this cultivar on 101-14 Mgt, which has a shorter cycle compared to other rootstocks. In addition, 101-14 Mgt is considered a weak rootstock that transmits less vigor to the scion (HARDIE; CIRAMI, 1988; CHRISTENSEN et al., 2003). In fact, it yielded lower $(\mathrm{p}<0.001)$ than $\mathrm{CS} / \mathrm{SO} 4, \mathrm{CS} /$ Solferino and CS/ Fercal in an earlier experiment carried out over two years (MIELE; RIZZON, 2017a).

The effect of rootstock on Cabernet Sauvignon grape juice at maturity is shown by research carried out under different conditions, such as those in which the rootstock had little or no effect on the total soluble solids (NUZZO; MATTHEWS, 2006; KELLER et al., 2012). On the other hand, there are studies reporting that the rootstock increased significantly the total soluble solids of grape juices from grafted grapevines (REYNOLDS; WARDLE, 2001; BERDEJA et al., 2014). The same behavior was observed with the titratable acidity, where higher values were found in the juice of Folha de Figo (syn. Ives, Bordô) grafted on nine rootstocks (MOTA et al., 2009). However, titratable acidity was not strongly affected by rootstocks (REYNOLDS; WARDLE, 2001) or it had no effect at all (KAMILOGLU, 2012). Similar patterns were found for both total soluble solids and titratable acidity in a study carried out with own-rooted and grafted Kyoho on $5 \mathrm{C}$ and $1202 \mathrm{C}$ rootstocks, in summer and winter crop cycles (CHOU; LI, 2014), and also with Gruener Veltliner grafted on seven rootstocks (KASERER et al., 1996).

The results of this study were probably due to a variety of factors, such as the source/sink relationship during the grape-ripening period, where the crop load might have played a role. However, an experiment carried out over four years under the same soil conditions comparing two pruning intensities and four thinning intensities showed that, on average, total soluble solids increased by only $0.47^{\circ}$ Brix whereas the yield per hectare decreased from $32.82 \mathrm{t} \mathrm{ha}^{-1}$ to $10.97 \mathrm{t} \mathrm{ha}^{-1}$ (MIELE; RIZZON, 2013). This data supports the idea that crop loadings may have had little effect on the differences found between treatments and it should also be mentioned that the climatic conditions, soil physicochemical characteristics and vineyard management were similar to those of the present experiment. The influence of the rootstock might also have had effect on the Cabernet Sauvignon grape composition due to differences in mineral uptake, its translocation in the xylem tissue and the synthesis of sugar and a wide range of substances. Another point to be considered is related to the root hormones, which could have influenced the early fruit development, which led to differences in grape composition at maturity (RASHEF et al., 2014).

There is an inverse relationship between the sugar content and the acidity during ripening of the grape. In fact, the lowest acidity of CS/101-14 Mgt grape juice is in agreement with its total soluble solids, which was one of the highest among all scion/rootstock combinations. Sucrose is transported to the phloem tissue of grapevines, which is broken down into the monosaccharides glucose and fructose in the berries. As the sugar concentration in the grape juice increases, the organic acids decrease. Besides, it has been shown that tartaric acid is not rapidly affected at high temperatures such as is malic acid (KLIEWER, 1971) and the increase in ratio of organic acid salts to free acids during grape ripening leads to the steady increase in pH (KLIEWER et al., 1967). This means there are fewer $\mathrm{H}$ cation in the solution and the $\mathrm{pH}$ of the grape juice increases. Another factor that influences the $\mathrm{pH}$ of grape juice is the K cation (KODUR, 2011), the higher the concentration, the higher the $\mathrm{pH}$ value.

The data of this study show there were some differences between the $15 \mathrm{CS} /$ rootstock combinations regarding the evolution of the variables related to sugar and acidity during the grape ripening period. However, earlier studies carried out with the same rootstocks did not find expressive differences in the Cabernet Sauvignon wine physicochemical composition (MIELE; RIZZON, 2019a) and wine sensory characteristics (MIELE; RIZZON, 2019b). 


\section{Conclusion}

Grape juice composition varies according to the $\mathrm{CS} /$ rootstock and to the stage in which they are sampled. The CS/101-14 Mgt, in both veraison and maturity stage, has high values of the variables related to sugar - density, total soluble solids, $\mathrm{pH}$ and total soluble solids/titratable acidity ratio - and the CS/Fercal and CS/Dogridge have high values of titratable acidity.

Density, total soluble solids, $\mathrm{pH}$ and total soluble solids/titratable acidity ratio increase as the grape ripens while titratable acidity decrease. However, the increase and decrease rate are lower at the end of the grape ripening period.

The CS/99 R has the highest daily rate of total soluble solids increase and CS/Dogridge has the highest titratable acidity decrease.

\section{Acknowledgements}

The authors would like to thank Embrapa Uva e Vinho colleagues, who worked for nine years in this experiment, and Inra-Centre Bordeaux-Aquitaine for the kindness of providing the Fercal and Gravesac rootstocks for this research.

\section{References}

BERDEJA, M.; HILBERT, G.; LAFONTAINE, M.; STOLL, M.; GOMES, E.; RENAUD, C.; DELROT, S. Effects of drought stress and rootstock genotype on grape berry quality. Acta Horticulturae, The Hague, n.1038, p.375-377, 2014.

CHOU, M-I.; LI, K-T. Rootstock and seasonal variations affect anthocyanin accumulation and quality traits of 'Kyoho' grape berries in subtropical double cropping system. Vitis, Siebeldingen, v.53, n.4, p.193-199, 2014.

CHRISTENSEN, L.P.; DOKOOZLIAN, N.; WALKER, M.A.; WOLPERT, J.A. Wine grape in California. Oakland: University of California Agricultural and Natural Resources, 2003. (Publication, 3419).

FLORES, C.A.; PÖTTER, R.O.; SARMENTO, E.C.; WEBER, E.J.; HASENACK, H. Os solos do Vale dos Vinhedos. Brasília: Embrapa, 2012. 176p.

HARDIE, W.J.; CIRAMI, R.M. Grapevine rootstocks. In: COOMBE, B.G.; DRY, P.R. Viticulture. Resources. Adelaide: Winetitle, 1988. v.1. p.154-176.
JONES, T.H.; CULLIS, B.R.; CLINGELEFFER, P.R.; RÜHL, E.H. Effects of novel hybrid and traditional rootstocks on vigour and yield components of Shiraz grapevines. Australian Journal of Grape and Wine Research, Adelaide, v.15, n.3, p.284-292, 2009.

KAMILOGLU, Ö. The effects of rootstocks and training systems on the growth and fruit quality of the 'Round Seedless' grape. Journal of Food Agriculture and Environment, Helsinki, v.10, n.1, p.350-354, 2012.

KASERER, H.; BLAHOUS, D.; BRANDES, D. Optimizing wine grape quality by considering rootstockscion interaction. Acta Horticulturae, The Hague, n.427, p.267-276, 1996.

KELLER, M.; MILLS, L.J.; HARBERTSON, J.F. Rootstock effects on deficit-irrigated winegrapes in a dry climate: vigor, yield formation, and fruit ripening. American Journal of Enology and Viticulture, Davis, v.63, n.1, p.29-39, 2012.

KLIEWER, W.M. Effect of day temperature and light intensity on concentration of malic and tartaric acids in Vitis vinifera L. grapes. Journal of the American Society of Horticultural Science, Mount Vernon, v.96, p.372377, 1971.

KLIEWER, W.M.; HOWARTH, L.; OMORI, M. Concentration of tartaric acid and malic acid and their salts in Vitis vinifera grapes. American Journal of Enology and Viticulture, Davis, v.18, n.1, p.42-54, 1967.

KODUR, S. Effects of juice $\mathrm{pH}$ and potassium on juice and wine quality, and regulation of potassium in grapevines through rootstocks (Vitis): a short review. Vitis, Siebeldingen, v.59, n.1, p.1-6, 2011.

LEÃO, P.C de S.; BRANDÃO, E.O.; GONÇALVES, N.P. da S. Produção e qualidade de uvas de mesa 'Sugraone' sobre diferentes porta-enxertos no submédio do Vale do São Francisco. Ciência Rural, Santa Maria, v.41, n.9, p.1526-1531, 2011.

MIELE, A.; RIZZON, L.A. Intensidades da poda seca e do desbaste de cacho na composição da uva Cabernet Sauvignon. Revista Brasileira de Fruticultura, Jaboticabal, v.35, n.4, p.1081-1092, 2013.

MIELE, A.; RIZZON, L.A. Rootstock-scion interaction: 1. Effect on the yield components of the Cabernet Sauvignon grapevine. Revista Brasileira de Fruticultura, Jaboticabal, v.39, n.1, (e-820), 2017a. 
MIELE, A.; RIZZON, L.A. Rootstock-scion interaction: 2. Effect on the composition of Cabernet Sauvignon grape must. Revista Brasileira de Fruticultura, Jaboticabal, v.39, n.3, (e-434), 2017b.

MIELE, A.; RIZZON, L.A. Rootstock-scion interaction: 3. Effect on the Cabernet Sauvignon wine composition. Revista Brasileira de Fruticultura, Jaboticabal, v.41, n.1, 2019a.

MIELE, A.; RIZZON, L.A. Rootstock-scion interaction: 4. Effect on the sensory characteristics of Cabernet Sauvignon wine. Revista Brasileira de Fruticultura, Jaboticabal, v.41, n.1, 2019b.

MOTA, R.V. da; SOUZA, C.R. de; FAVERO, A.C.; SILVA, C.P.C.; CARMO, E.L. do; FONSECA, A.R.; REGINA, M. de A. Produtividade e composição físicoquímica de bagas de cultivares de uva em diferentes portaenxertos. Pesquisa Agropecuária Brasileira, Brasília, DF, v.44, n.6, p.576-582, 2009.

NUZZO, V.; MATTHEWS, M.A. Response of fruit growth and ripening to crop level in dry-farmed Cabernet Sauvignon on four rootstocks. American Journal of Enology and Viticulture, Davis, v.57, n.3, p.314-324, 2006.

RASHEF, N.; AKERMAN, M.; VARDAKA, P.; DAL MOLIN, A.; FERRARINI, A.; FAIT, A.; DELLEDONNE, F.; OR, E. From root-to-fruit: how rootstocks alter the development, molecular phenology and chemical composition of the grape. In: INTERNATIONAL SYMPOSIUM ON GRAPEVINE ROOTS, 1., 2014, Rauscedo. Book of Abstracts [...]. Rauscedo: Consiglio per la Ricerca e la Sperementazione in Agricoltura; Vivai Cooperativi Rauscedo, 2014. p.53.
REYNOLDS, A.G.; WARDLE, D.A. Rootstocks impact vine performance and fruit composition of grapes in British Columbia. HortTechnology, Alexandria, v.11, n.3, p.419-427, 2001.

RIBÉREAU-GAYON, J.; PEYNAUD, E.; SUDRAUD, P.; RIBÉREAU-GAYON, P. Traité d'œnologie: sciences et techniques du vin: analyse et contrôle des vins. $2^{\text {nd }} \mathrm{ed}$. Paris: Dunod, 1982. v.1.

SATISHA, J.; SOMKUWAR, R.G.; SHARMA, J.; UPADHYAY, A.K.; ADSULE, P.G. Influence of rootstocks on growth, yield and fruit composition of Thompson Seedless grapes grown in the Pune Region of India. South African Journal of Enology and Viticulture, Stellenbosch, v.31, n.1, p.1-8, 2010.

SOUZA, C.R. de; MOTA, R.V. da; FRANÇA, D.V.C.; PIMENTEL, R.M. de A.; REGINA, M. de A. Cabernet Sauvignon grapevine grafted onto rootstocks during the autumn-winter season in southeastern Brazilian. Scientia Agricola, Piracicaba, v.72, n.2, p.138-146, 2015.

WINKLER, A.J.; COOK, J.A.; KLIEWER, W.M.; LIDER, L.A. General viticulture. Berkeley: University of California, 1974. 